\title{
In vitro activity of Artemisia annua L (Asteraceae) extracts against Rhipicephalus (Boophilus) microplus
}

Atividade in vitro de extratos de Artemisia annua L (Asteraceae) sobre Rhipicephalus (Boophilus) microplus

Ana Carolina de Souza Chagas ${ }^{1 *}$; Cynthia Sanches Georgetti²; Camila Olivo de Carvalho3; Márcia Cristina de Sena Oliveira ${ }^{1}$; Rodney Alexandre Rodrigues ${ }^{4}$; Mary Ann Foglio ${ }^{4}$; Pedro Melillo de Magalhães ${ }^{4}$

${ }^{1}$ Laboratório de Sanidade Animal, Embrapa Pecuária Sudeste, Empresa Brasileira de Pesquisa Agropecuária - EMBRAPA

${ }^{2}$ Centro Universitário Central Paulista - UNICEP

${ }^{3}$ Universidade Estadual Paulista - UNESP

${ }^{4}$ Centro Pluri-disciplinar de Pesquisas Químicas, Biológicas e Agrícolas, Universidade Estadual de Campinas - UNICAMP

Received August 24, 2010

Accepted November 29, 2010

\begin{abstract}
The activity of plant extracts on parasites may indicate groups of substances that are potentially useful for controlling Rhipicephalus (Boophilus) microplus. The aim of the present study was to investigate the in vitro action of Artemisia annua extracts on this tick. The concentrations of the sesquiterpene lactones artemisinin and deoxyartemisinin present in plant extracts were quantified via high-performance liquid chromatography. Four extracts produced from the concentrated crude extract (CCE) were evaluated on larvae using the impregnated paper method, with readings after 24 hours of incubation. The engorged females were immersed in the CCE and in its four derived extracts for five minutes, with incubation for subsequent analysis of biological parameters. The extracts were not effective on the larvae at the concentrations tested $\left(3.1\right.$ to $\left.50 \mathrm{mg} \cdot \mathrm{mL}^{-1}\right)$. The CCE showed greater efficacy on engorged females $\left(\mathrm{EC}_{50}\right.$ of $130.6 \mathrm{mg} \cdot \mathrm{mL}^{-1}$ and $\mathrm{EC}_{90}$ of $\left.302.9 \mathrm{mg} \cdot \mathrm{mL}^{-1}\right)$ than did the derived extracts. These results tend to confirm that the action of artemisinin on engorged females of $R$. (B.) microplus is conditional to their blood intake. In this case, in vitro methods would be inadequate for effective evaluation of the action of $A$. annua on $R$. (B.) microplus.
\end{abstract}

Keywords: Phytotherapy, artemisinin, tick, control, R. (B.) microplus, Artemisia annua.

\section{Resumo}

A atividade de extratos vegetais sobre parasitas pode indicar grupos de substâncias de uso potencial no controle de Rhipicephalus (Boophilus) microplus. O objetivo do presente estudo foi investigar a ação in vitro de extratos de Artemisia апnua sobre esta espécie. A concentração das lactonas sesquiterpênicas artemisinina e deoxiartemisinina presentes nos extratos vegetais, foi quantificada via cromatografia líquida de alta eficiência. Quatro extratos produzidos a partir do extrato bruto concentrado (EBC) foram avaliados sobre larvas pela metodologia do papel impregnado, com leitura após 24 horas de incubação. As fêmeas ingurgitadas foram imersas por cinco minutos no EBC e nos seus quatro extratos derivados, e incubadas para posterior análise dos parâmetros biológicos. Os extratos não tiveram eficácia sobre as larvas nas concentraçóes avaliadas (de 3,1 a $50 \mathrm{mg} \cdot \mathrm{mL}^{-1}$ ). O EBC apresentou melhor eficácia sobre as fêmeas ingurgitadas $\left(\mathrm{CE}_{50}\right.$ de 130,6 mg.mL $\mathrm{mL}^{-1}$ e $\mathrm{CE}_{90}$ de 302,9 mg. $\mathrm{mL}^{-1}$ ) que os extratos derivados. Esses resultados tendem a confirmar que a ação da artemisinina sobre as fêmeas ingurgitadas de $R$. (B.) microplus estaria condicionada à sua ingestão através do sangue. Nesse caso, os métodos in vitro seriam inadequados para a efetiva avaliação da ação de $A$. annua sobre R. (B.) microplus.

Palavras-chave: Fitoterapia, artemisinina, carrapato, controle, $R$. (B.) microplus, Artemisia annua.

\footnotetext{
*Corresponding author: Ana Carolina de Souza Chagas

Laboratório de Sanidade Animal, Embrapa Pecuária Sudeste

Rod. Washington Luiz, Km 234, CP 339, CEP 13560-970,

São Carlos - SP, Brasil;

e-mail: carolina@cppse.embrapa.br
} 


\section{Introduction}

Good results from cattle rearing depend on nutritional, reproductive and health management, among other factors. In health management, parasite control is a major challenge, since rearing implies inevitable parasitic infestation. Brazil has one of the largest cattle herds in the world, estimated at 173.2 million head (ANUALPEC, 2009). Rhipicephalus (Boophilus) microplus tick (Canestrini, 1887) is considered largely responsible for economic losses in cattle production. Research has shown that Brazil spends about 800 million dollars a year on acaricides to combat this parasite (FURLONG et al., 2007). However, control using chemicals has become increasingly less tenable for a number of reasons, such as high cost, short time of effectiveness, rapid development of resistance, inadequate management and disregard of the lack of time and possibility of pesticide waste in the environment and products of animal origin (GRISI et al., 2002).

For this reason, searching for new alternatives to conventional acaricides for parasite control has become inevitable. Several specific investigations have been conducted on $R$. (B.) microplus, in which the antiparasitic potential and bioactivity of plant extracts have been evaluated. The essential oil of Eucalyptus staigeriana (Myrtaceae) has been tested on larvae and engorged females and was found to cause mortality ranging from 12.5 to $100 \%$. When the oil was turned into an emulsifiable concentrate, efficiency of $100 \%$ was obtained at a concentration of 3.9\% (CHAGAS et al., 2002). In vivo tests have shown that the $0.25 \%$ hexane extract of Melia azedarach (Meliaceae) reduced the infestation of $R$. (B.) microplus by around 24\% (BORGES et al., 2005). The essential oil of Cymbopogon winterianus (Poaceae) at $7 \%$ concentration inhibited $100 \%$ of egg hatchability in treated engorged females, although the compound isolated were not so effective (MARTINS, 2006). The $2.7 \%$ alcoholic extract of Cymbopogon citratus caused mortality of $43 \%$ in the field (HEIMERDINGER et al., 2006). The oil of Copaifera reticulata (Caesalpiniaceae) presented an $\mathrm{EC}_{99}$ of $3.5 \mathrm{ppm}$ for larvae (FERNANDES; FREITAS, 2007). The hexane extract of Hypericum polyanthemum (Guttiferaceae) killed 100\% of the larvae at $6.25 \mathrm{mg} \cdot \mathrm{mL}^{-1}$ (RIBEIRO et al., 2007).

Artemisia annua L (Asteraceae) (the target of the present study) and other species of this genus contain a sesquiterpene lactone called artemisinin, which has already been proven to have antimalarial activity. The mechanisms of action, clinical characteristics and toxicity of artemisinin have been studied extensively. Agrotechnological, pharmacological and chemical studies have also been conducted on other sesquiterpene compounds present in this plant (RODRIGUES et al., 2006). In addition to the rapid action of artemisinin at nanomolar concentrations for controlling Plasmodium spp. (CREEK et al., 2005; FERREIRA et al., 2006), the genus Artemisia also has an effect on gastrointestinal nematodes, thereby decreasing the number of eggs per gram of feces (EPG) in small ruminants (IDRIS et al., 1982; IQBAL et al., 2004; TARIQ et al., 2009). There have not been any specific studies in the literature examining the action of $A$. annua on the tick $R$. (B.) microplus. Hence, the present study aimed to evaluate the effect of extracts of $A$. annua on $R$. (B.) microplus, and to identify and quantify its constituents, thus providing future possibilities for preparing safe, standardized and commercially available formulations for farmers.

\section{Material and Methods}

\section{Production of $A$. annua extracts}

A. annua leaves and twigs genotype $\mathrm{Ch} \times \mathrm{Viet55}$, which was selected for late flowering and was cultivated in the Multidisciplinary Centre for Chemical, Biological and Agricultural Research (CPQBA) at UNICAMP, was used throughout the present study. To extract the active ingredients, the traditional method was used on a weight of $1 \mathrm{~kg}$ of dried and ground plant material. In this process, the plant was subjected to extraction using ethanol $\left(96^{\circ} \mathrm{GL}\right)$ as the extractor liquid at room temperature, with the aid of mechanical agitation for $4 \frac{1}{2}$ hours $\left(3 \times 1 \frac{1}{2}\right.$ hours $)$. The extracts were filtered, pooled and concentrated to $1 / 3$ of the total volume, thus providing the so-called concentrated crude extract (CCE), which was subjected to evaporation. From this extract, another four extracts were produced under cold conditions in accordance with Simóes et al. (2004), using different solvents for non-sequential extraction in: A) water followed by lyophilization; B) water basified with $\mathrm{NaHCO}_{3}$ (sodium bicarbonate) at $0.1 \%$; C) ethanol $\left(96^{\circ} \mathrm{GL}\right)$, followed by concentration in a rotary evaporator; and D) dichloromethane, followed by concentration in a rotary evaporator.

\section{Quantification of artemisinin and deoxyartemisinin in the A. annua extracts}

The extracts were suspended in $5.0 \mathrm{~mL}$ volumetric flasks with chromatographic-grade methanol, filtered through $0.45 \mu \mathrm{m}$ Millipore and analyzed by means of refractive index highperformance liquid chromatography (RI-HPLC). To prepare the mobile phase, $60: 40$ solvents of $\mathrm{H}_{2} \mathrm{O}$ to $\mathrm{MeOH}$ were used, with filtration on $0.45 \mu \mathrm{m}$ Millipore and sonication under vacuum. To prepare the calibration curve, $65 \mathrm{mg}$ of the extracts was weighed, and this was diluted in $25 \mathrm{~mL}$ of HPLC-grade methanol, thereby resulting in a concentration of $2,444 \mu \mathrm{g} \cdot \mathrm{mL}^{-1}$, of analytical standard with $94 \%$ purity. Injections in triplicate were made at seven points on the analytical curve, at concentrations from 50 to $1,250 \mu \mathrm{g} . \mathrm{mL}^{-1}$, and the curve was obtained through the Empower software. The chromatograph was used equipped with an ionization detector and a Phenomenex Luna CN $100 \mathrm{~A}^{\circ}$ capillary column $(250 \mathrm{~mm} \times 4.6 \mathrm{~mm} \times 5 \mu \mathrm{m})$, and with volume injection of $20 \mu \mathrm{L}$ and flow rate of $1 \mathrm{~mL} / \mathrm{min}$. This procedure had a sensitivity of $32^{\circ} \mathrm{C}$ and internal temperature of $35^{\circ} \mathrm{C}$. The quantification of artemisinin (retention time of 7 minutes) and deoxyartemisinin (6.5 minutes) content in the extracts was done using the methodology validated by Celeghini et al. (2009), from the external standard method.

\section{Sensitivity of larvae in the impregnated paper test}

Engorged females from the colony of $R$. (B.) microplus that is maintained by Embrapa Pecuária Sudeste (CPPSE) were placed in an incubator $\left( \pm 27^{\circ} \mathrm{C}\right.$ and $\left.\mathrm{RH}>80 \%\right)$ for larvae production, for use 14 to 21 days after hatching. The extracts were tested at five concentrations: aqueous (A) and sodium bicarbonate (B) extracts 
were used at concentrations ranging from 12.5 to $50 \mathrm{mg} \cdot \mathrm{mL}^{-1}$; and ethanol (C) and dichloromethane extracts (D) between 3.1 and $12.5 \mathrm{mg} \cdot \mathrm{mL}^{-1}$. These concentrations were defined according to the available quantity of each of the extracts and from in vitro results with eggs and larvae of gastrointestinal nematodes (CALA, 2010). The ethanol extracts were dissolved in $0.33 \%$ Tween 80 and $10 \%$ ethanol, with one control consisting of distilled water and another of distilled water, and the other solvents at the same concentrations. All tests were conducted with three replications.

Approximately 100 larvae were placed between $2 \times 2 \mathrm{~cm}$ filter papers that had newly been impregnated with the extracts, thereby forming a sandwich. This was placed inside a filter paper envelope and sealed. This approach is recommended by the World Food and Agriculture Organization (CHAGAS et al., 2003). The envelopes were kept in an incubator $\left( \pm 27^{\circ} \mathrm{C}\right.$ and $\left.\mathrm{RH}>80 \%\right)$ and counting of live and dead larvae was performed after 24 hours. To calculate the percentage mortality, the following formulas were used:

$$
\begin{aligned}
& \text { Mortality }(\%)=\frac{\text { dead larvae } \times 100}{\text { total larvae }} \\
& \text { Average Mort. }(\%)=\frac{(\text { mort. replication } 1)+(\text { mort. replication } 2)}{+(\text { mort. replication 3) }}
\end{aligned}
$$

\section{Sensitivity of engorged females in the immersion test}

Engorged females collected from cattle at CPPSE were weighed in order to form homogeneous groups of 10 females, which were immersed for 5 minutes in the plant extracts tested (DRUMMOND et al., 1973). After this period, the females were removed from the solution, dried on paper towels and placed in properly identified Petri dishes bearing double-sided tape. The groups were placed in the incubator $\left(27^{\circ} \mathrm{C}\right.$ and $\left.\mathrm{RH}>80 \%\right)$ for 18 days and, after the spawning period, the eggs were weighed and transferred to properly labeled syringes, sealed and placed in the incubator. The hatchability was verified visually by comparing the number of remaining eggs with the shells (AMARAL, 1993).

Because the expected effectiveness was not obtained in the larva test, the immersion test on engorged females was set at higher concentrations, but again respecting the availability of each extract. Five concentrations were evaluated: aqueous extracts (A) from 40 to $280 \mathrm{mg} \cdot \mathrm{mL}^{-1}$; sodium bicarbonate extracts (B) and dichloromethane extracts (D) from 20 to $220 \mathrm{mg} \cdot \mathrm{mL}^{-1}$; and ethanol extracts (C) and CCE extracts from 10 to $140 \mathrm{mg} \cdot \mathrm{mL}^{-1}$. Three replicates were performed for each concentration and the solvents $0.33 \%$ Tween 80 and $10 \%$ ethanol were used for the ethanol extracts. Control groups were prepared with solvents as mentioned above. Toxicity limits had been determined previously (CHAGAS et al., 2003). The percentage efficiency was calculated in accordance with Drummond et al. (1973):

\footnotetext{
Reproductive $=$ egg weight $\times \% \times 20,000$ hatching ${ }^{*}$ efficience index: REI $=\frac{\text { weight of engorged females }}{\text {. }}$

*Constant that indicates the number of eggs present in $1 \mathrm{~g}$.

$\begin{gathered}\text { Extract } \\ \text { effectiveness: } \mathrm{EE}\end{gathered}=\frac{(\mathrm{ER} \text { control }-\mathrm{ER} \text { treated })}{\mathrm{ER} \text { control }} \times 100$
}

The results were analyzed using the Probit procedure (from SAS) to determine the $\mathrm{EC}_{50}$ and $\mathrm{EC}_{99}$. The data on the five concentrations were compared within each extract using the Tukey test.

\section{Results}

The chemical analyses on the four plant extracts enabled quantification of artemisinin (to which antiparasitic action has been attributed) and deoxyartemisinin, another sesquiterpene lactone that is present in extracts from this species (Table 1). Taking the values found, it was observed that the dichloromethane extract (D) had the highest amounts of artemisinin and deoxyartemisinin, followed by the ethanol extract (C).

All the larvae remained alive after exposure to the extracts at all the concentrations tested. In the immersion test, no significant action was seen at any concentration for the four extracts derived. It was only possible to calculate the $\mathrm{EC}_{50}$ and $\mathrm{EC}_{90}$ for the CCE extract ( $p \geq 0.05): 130.6 \mathrm{mg} \cdot \mathrm{mL}^{-1}$ (115.9 to 152.7$)$ and $302.9 \mathrm{mg} \cdot \mathrm{mL}^{-1}$ (238.6 to 436.0 ), respectively. The results regarding reproductive efficiency and the effectiveness of the CCE and its four derivative extracts can be seen in Table 2.

\section{Discussion}

From assessment of the records of $A$. annua activity on a variety of parasites, it was decided to evaluate its potential for controlling the tick $R$. (B.) microplus. It was observed in the larva test that the four extracts of $A$. annua had no effectiveness at the concentrations evaluated. There was an expectation of better results with dichloromethane, which contained a large amount of artemisinin (1343.9 g. $\mathrm{mL}^{-1}$ ) because of its high affinity for the solvent, which could explain its more significant biological activity. One factor that may have affected the results was the cracking condition of the CCE; other substances that might have been acting synergistically within the antiparasitic effect were diluted in the subsequent four extracts, thereby resulting in lower effectiveness for the dichloromethane extract than for the CCE.

Doses of Artemisia herba-alba from 2 to $30 \mathrm{~g}$ were administrated orally to goats that had been artificially infected with the gastrointestinal nematode $H$. contortus. There was a reduction in EPG in the abomasum of adults, as well as reductions in histological damage or blood disorders (IDRIS et al., 1982). In sheep that received the crude ethanol and methanol extracts of Artemisia brevifolia for 14 days, at doses of $3.0 \mathrm{~g} . \mathrm{kg}^{-1}$ body weight (bw), EPG reductions of 67.2 and $62.1 \%$ were detected (IQBAL et al., 2004). Aqueous and ethanol crude extracts of Artemisia absinthium were also administered orally to infected sheep, and there was a reduction in EPG: in the aqueous extract, $80.49 \%$ was obtained at a dose of $2 \mathrm{~g} \cdot \mathrm{kg}^{-1} \mathrm{bw}$ and in the ethanol extract, $90.46 \%$ at a dose of $2{\mathrm{~g} . \mathrm{kg}^{-1}}^{\mathrm{bw}}$ and $82.85 \%$ at a dose of $1 \mathrm{~g} . \mathrm{kg}^{-1}$ bw (TARIQ et al., 2009).

Although artemisinin-derived drugs have shown effects on a variety of parasites such as Fasciola hepatica and gastrointestinal nematodes in small ruminants. Plasmodium spp., Coccidia spp., Babesia spp., Leishmania spp., Neospora caninum and Schistosoma spp., and have been successfully tested as cancer 
Table 1. Quantification of the sesquiterpene lactones artemisinin and deoxyartemisinin ( $\mu \mathrm{g} \cdot \mathrm{mL}^{-1}$ ) in aqueous, sodium bicarbonate, ethanol and dichloromethane extracts of Artemisia annua, via highperformance liquid chromatography.

\begin{tabular}{clrc}
\hline Code & \multicolumn{1}{c}{ Extract } & Artemisinin & Deoxyartemisinin \\
\hline A & Aqueous & 108.627 & 38.068 \\
B & Sodium bicarbonate & 93.476 & 37.532 \\
C & Ethanol & 989.985 & 289.054 \\
D & Dichloromethane & $1,343.929$ & 316.838 \\
\hline
\end{tabular}

Table 2. Reproductive efficiency index (REI) and extract effectiveness (EE) in engorged females of Rhipicephalus (Boophilus) microplus, tested by means of immersion in different concentrations (mg. $\left.\mathrm{mL}^{-1}\right)$ of Artemisia annua extracts: concentrated crude extract (CCE), aqueous, sodium bicarbonate, ethanol and dichloromethane.

\begin{tabular}{|c|c|c|c|c|}
\hline Extract & Concentration & REI & EE & * \\
\hline \multirow[t]{5}{*}{ CCE } & 10 & 95 & 0.0 & $\mathrm{a}$ \\
\hline & 20 & 95 & 0.0 & a \\
\hline & 40 & 91 & 4.2 & $\mathrm{a}$ \\
\hline & 80 & 68 & 28.4 & $\mathrm{~b}$ \\
\hline & 140 & 45 & 52.6 & c \\
\hline \multirow[t]{5}{*}{ Aqueous } & 40 & 94 & 0.7 & $\mathrm{a}$ \\
\hline & 80 & 92 & 2.7 & a \\
\hline & 160 & 86 & 9.2 & a \\
\hline & 220 & 88 & 6.8 & $\mathrm{a}$ \\
\hline & 280 & 83 & 12.5 & $\mathrm{a}$ \\
\hline \multirow[t]{5}{*}{ Sodium bicarbonate } & 20 & 85 & 10.7 & a \\
\hline & 40 & 78 & 17.3 & a \\
\hline & 80 & 80 & 15.7 & a \\
\hline & 160 & 84 & 11.7 & a \\
\hline & 220 & 75 & 21.0 & $\mathrm{a}$ \\
\hline \multirow[t]{5}{*}{ Ethanol } & 40 & 81 & 14.1 & a \\
\hline & 80 & 65 & 31.0 & a \\
\hline & 160 & 92 & 2.8 & a \\
\hline & 220 & 78 & 17.5 & $\mathrm{a}$ \\
\hline & 280 & 76 & 19.4 & $\mathrm{a}$ \\
\hline \multirow[t]{5}{*}{ Dichloromethane } & 20 & 88 & 6.8 & a \\
\hline & 40 & 86 & 9.0 & a \\
\hline & 80 & 75 & 18.0 & a \\
\hline & 160 & 82 & 13.1 & a \\
\hline & 220 & 91 & 3.5 & a \\
\hline
\end{tabular}

*Different letters in the same column represent a difference. $(p \geq 0.5)$ within the same extract.

treatments (FERREIRA, 2007), they were not shown to be effective on $R$. (B.) microplus in the present study. Derivatives devoid of the peroxide bond, such as deoxyartemisinin, are considered completely inactive on parasites. Thus, the fundamental group that confers activity to artemisinin, and even to synthetic substances, is lead peroxide (KLAYMAN, 1985; MESHNICK et al., 1996). Endoperoxides are classified as blood schizonticidal agents in the case of Plasmodium spp. control in malaria (TARANTO et al, 2006).

The mode of action of artemisinin in gastrointestinal nematodes, trematodes and monogeneans has been extensively investigated (KEISER et al., 2006, 2008; EKANEM; BRISIBE, 2010). Such studies may explain how artemisinin can be applied to control other parasites of veterinary importance, such as $R$. (B.) microplus. Artemisinin is thought to exert its effect by reacting with the heme groups of the hemoglobin molecules digested by parasites, altering the cell structure and its functions through the free radicals derived from artemisinin, and thus affect the growth and reproduction of parasites (WRIGHT; WARHURST, 2002 apud FERREIRA; GONZALEZ, 2008). In this manner, it can be claimed that the action of artemisinin occurs in two steps: first, there is the generation of free radical; and then, alkylation of specific proteins that are essential for parasite survival (SILVA, 2006). Indeed, such generation of free radicals depends on iron ions present in the heme group, and this is the major step of the mechanism of action, since the formation of a complex between the heme group and artemisinin causes disruption of the endoperoxide bridge by means of catalytic reduction (LA-SCALEA et al., 2007). However, in addition to the feeding mechanism, which enables breakage of the peroxide bridge, other mechanisms may also be involved, since artemisinin has been shown to have action against the nonhematophagous parasite Echinostoma caproni in mice (KEISER; UTZINGER, 2007).

Thus, if the mode of action of artemisinin on the parasite is indirect, i.e. impairing its reproduction, for example, its efficacy on engorged $R$. (B.) microplus would be conditional on its intake through the blood. The same has been said for gastrointestinal nematodes in small ruminants (FERREIRA et al., 2006). If ingestion is the process that activates the main mechanism of action of artemisinin in $R$. (B.) microplus, in vitro methods would be inadequate for effective evaluation of $A$. annua in this parasite. Thus, we now intend to conduct in vivo tests at CPPSE, in which cattle may receive $A$. annua in food, in order to elucidate this hypothesis.

\section{References}

AMARAL, N. K. Guidelines for the evaluation of ixodicides against the cattle tick Boophilus microplus (Canestrini, 1887) (Acari: Ixodidae). Revista Brasileira de Parasitologia Veterinária, v. 2, n. 2, p. 144-151, 1993.

ANUALPEC. Anuário da pecuária brasileira. São Paulo: Angra FNP Pesquisas. 2009, 360 p.

BORGES, L. M. F. et al. Ação do extrato hexânico de frutos maduros de Melia azedarach (Meliaceae) sobre Boophilus microplus (Acari: Ixodidae) em bezerros infestados artificialmente. Revista de Patologia Tropical, v. 34, n. 1, p. 53-59, 2005.

CALA, A. C. Avaliaçáo da atividade de Artemisia annua L., Melia azedarach L. e Trichilia claussenii C. sobre nematódeos gastrintestinais de ovinos. 2010. 64 f. Dissertação (Mestrado)Universidade Estadual Paulista, Faculdade de Ciências Agrárias e Veterinárias, Jaboticabal.

CELEGHINI, R. M. S. et al. Desenvolvimento e validação de metodologia analítica por CLAE-IR para determinação de artemisinina em Artemisia annua L. Química Nova, v. 32, n. 4, p. 875-878, 2009.

CHAGAS, A. C. S. et al. Efeito acaricida de óleos essenciais e concentrados emulsionáveis de Eucalyptus em Boophilus microplus. Brazilian Journal of Veterinary Research and Animal Science, v. 39, n. 5, p. 247-253, 2002. 
CHAGAS, A. C. S. et al. Sensibilidade do carrapato Boophilus microplus a solventes. Ciência Rural, v. 33, n. 1, p. 109-114, 2003.

CREEK, D. J. et al. Kinetics of ironmediated artemisinin degradation: effect of solvent composition and iron salt. Journal of Pharmaceutical Sciences, v. 94, n. 8, p. 1820-1829, 2005.

DRUMMOND, R. O. et al. Boophilus annulatus and B. microplus: laboratory tests of insecticides. Journal of Economic Entomology, v. 66, n. 1, p. $130-133,1973$.

EKANEM, A. P.; BRISIBE, E. A. Effects of ethanol extract of Artemisia annua L. against monogenean parasites of Heterobranchus longifilis. Parasitology Research, v. 106, n. 5, p. 1135-1139, 2010.

FERNANDES, F. F.; FREITAS, E. P. S. Acaricidal activity of an oleoresinous extract from Copaifera reticulata (Leguminosae: Caesalpinioideae against larvae of the southern cattle tick, Riphicephalus (Boophilus) microplus (Acari:Ixodidae). Veterinary Parasitology, v. 147, n. 1-2, p. 150-154, 2007.

FERREIRA, J. F. S. et al. Agrotechnological aspects of the anti-malarial plant Artemisia annua and its potential use in animal health in Appalachia. In: Revue de Régions Arides - Numéro special - Actes du séminaire international les Plants à Parfum, Aromatiques et Medicinales (English version: International Center for Agricultural Research in Dry Areas, International Symposium on Perfume, Aromatic and Medicinal Plants, n. 2-4, p. 797-804, 2006.

FERREIRA, J. F. S. Nutrient Deficiency in the Production of Artemisinin, Dihydroartemisinic Acid, and Artemisinic Acid in Artemisia annua L. Journal of Agricultural and Food Chemistry, v. 55, n. 5 , p. 1686-1694, 2007.

FERREIRA, J. F. S.; GONZALEZ, J. M. Chemical and biological stability of artemisinin in bovine rumen fluid and its kinetics in goats (Capra hircus). Revista Brasileira de Parasitologia Veterinária, v. 17, Supl. 1, p. 103-109, 2008.

FURLONG, J. et al. O carrapato dos bovinos e a resistência: temos o que comemorar? A Hora Veterinária, v. 159, p. 26-32, 2007.

GRISI, L. et al. Impacto econômico das principais ectoparasitoses em bovinos no Brasil. A Hora Veterinária, v. 21, n. 125, p. 8-10, 2002.

HEIMERDINGER, A. et al. Extrato alcoólico de Capim-cidreira (Cymbopogon citratus) no controle do Boophilus microplus em bovinos. Revista Brasileira de Parasitologia Veterinária, v. 15, n. 1, p. 37-39, 2006.

IDRIS, U. A.; ADAM, S. E.; TARTOUR, G. The anthelmintic efficacy of Artemisia herba-alba against Haemonchus contortus infection in goats. Animal Health Quarterly, v. 22, n. 3, p. 138-143, 1982.
IQBAL, Z. et al. Anthelmintic activity of Artemisia brevifolia in sheep. Journal of Ethnopharmacology, v. 93, n. 2, p. 265-268, 2004.

KEISER, J. et al. Artesunate and artemether are effective fasciolicides in the rat model and in vitro. Journal of Antimicrobial Chemotherapy, v. 57, n. 6, p. 1139-1145, 2006.

KEISER, J. et al. Efficacy and safety of artemether against a natural Fasciola hepatica infection in sheep. Parasitology Research, v. 103, n. 3, p. 517-522, 2008.

KEISER, J.; UTZINGER, J. Food-borne trematodiasis: current chemotherapy and advances with artemisinins and synthetic trioxolanes. Trends in Parasitology, v. 23, n. 11, p. 555-562, 2007.

KLAYMAN, D. L. Qinghaosu (Artemisinin): na antimalarial drug from China. Science, v. 228, n. 4703, p. 1049-1055, 1985.

LA-SCALEA, M. A.; SILVA, H. S. R. C.; FERREIRA, E. I. Redução voltamétrica de artemisinina e sua interação com grupo heme (hemina). Brazilian Journal of Pharmaceutical Sciences, v. 43, n. 3, p. 371-383, 2007.

MARTINS, R. M. Estudio in vitro de la acción acaricida del aceite esencial de la gramínea Citronela de Java (Cymbopogon winterianus Jowitt) en la garrapata Boophilus microplus. Revista Brasileira de Plantas Medicinais de Botucatu, v. 8, n. 2, p. 71-78, 2006.

MESHNICK, S. R. et al. Second-generation antimamalarial endoperoxides. Parasitology Today, v. 12, n. 2, p. 79-82, 1996.

RIBEIRO, V. L. S. et al. Acaricidal properties of extracts from the aerial parts of Hypericum polyanthemum on the cattle tick Boophilus microplus. Veterinary Parasitology, v. 147, n. 1-2, p. 199-203, 2007.

RODRIGUES, R. A. F. et al. Otimização do processo de extração e isolamento do antimalárico artemisinina a partir de Artemisia annua L. Química Nova, v. 29, n. 2, p. 368-372, 2006.

SILVA, H. S. R. C. Antimaláricos potenciais: pró-fármacos poliméricos e formas de liberaçáo controlada de artemisinina. 2006. 209 f. Tese (Doutorado)-Universidade de São Paulo, São Paulo.

SIMÓES, C. M. et al. Farmacognosia: da planta ao medicamento. 5. ed. Porto Alegre: Editora da UFRGS; Florianópolis: Editora da UFSC, 2004. 1102 p.

TARANTO, A. G. et al. Estudo sobre o mecanismo de ação da artemisinina e dos endoperóxidos, a mais nova classe de agentes antimaláricos. Sitientibus, v. 34, p. 47-58, 2006.

TARIQ, K. A. et al. Anthelmintic activity of extracts of Artemisia absinthium against ovine nematodes. Veterinary Parasitology, v. 160, n. 1-2, p. 83-88, 2009. 